\title{
Recurrent Acute Pancreatitis with a Bulging Papilla: An Unexpected Diagnosis
}

\author{
Marta Moreira ${ }^{a}$ João Fernandes ${ }^{a}$ Tarcísio Araújo $^{a}$ Richard Azevedo ${ }^{a}$ \\ Jorge Canena ${ }^{\mathrm{b}, \mathrm{c}}$ Luis Lopes ${ }^{\mathrm{a}}$, d, e \\ aDepartment of Gastroenterology, Santa Luzia Hospital, Unidade Local de Saúde Alto Minho, Viana do Castelo, \\ Portugal; ${ }^{b}$ Department of Gastroenterology, Professor Doutor Fernando Fonseca Hospital, Amadora, Portugal; \\ 'Department of Gastroenterology, Nova Medical School/Faculty of Medical Sciences, Lisbon, Portugal; ${ }^{\mathrm{d}}$ Life and \\ Health Sciences Research Institute (ICVS), School of Medicine, University of Minho, Braga, Portugal; 'ICVS/3B's, \\ PT Government Associate Laboratory, Braga/Guimarães, Portugal
}

\section{Keywords}

Recurrent acute pancreatitis - Bulging papilla - Bile duct adenoma

\section{Pancreatite aguda recorrente em doente com papila tumefacta: um diagnóstico inesperado}

\section{Palavras Chave}

Pancreatite aguda recorrente - Papila tumefacta .

Adenoma das vias biliares

Bile duct adenomas are a very rare entity, mostly located in the gallbladder and incidentally found in surgical specimens; however, they can be detected in any segment of the biliary tree [1]. The natural history of these lesions is not well established but is postulated to be similar to the adenoma-adenocarcinoma sequence existing elsewhere in the gastrointestinal tract [2].

We present the case of an 87-year-old man with a history of two episodes of acute pancreatitis, with a 3-month interval between them, referred for upper endoscopic ultrasound. This study showed a $15 \times 10 \mathrm{~mm}$ isoechoic image in the terminal portion of the common bile duct

karger@karger.com www.karger.com/pjg

Karger ${ }^{\prime \prime} \div$

GOPEN ACCESS

\section{(c) 2021 Sociedade Portuguesa de Gastrenterologia} Published by S. Karger AG, Basel

This is an Open Access article licensed under the Creative Commons Attribution-NonCommercial-4.0 International License (CC BY-NC) (http://www.karger.com/Services/OpenAccessLicense), applicable to the online version of the article only. Usage and distribution for commercial purposes requires written permission.
(CBD), with a heterogeneous aspect and no acoustic shadowing (Fig. 1). A subsequent endoscopic retrograde cholangiopancreatography (ERCP) was performed, revealing an enlarged and bulging papilla, with normal

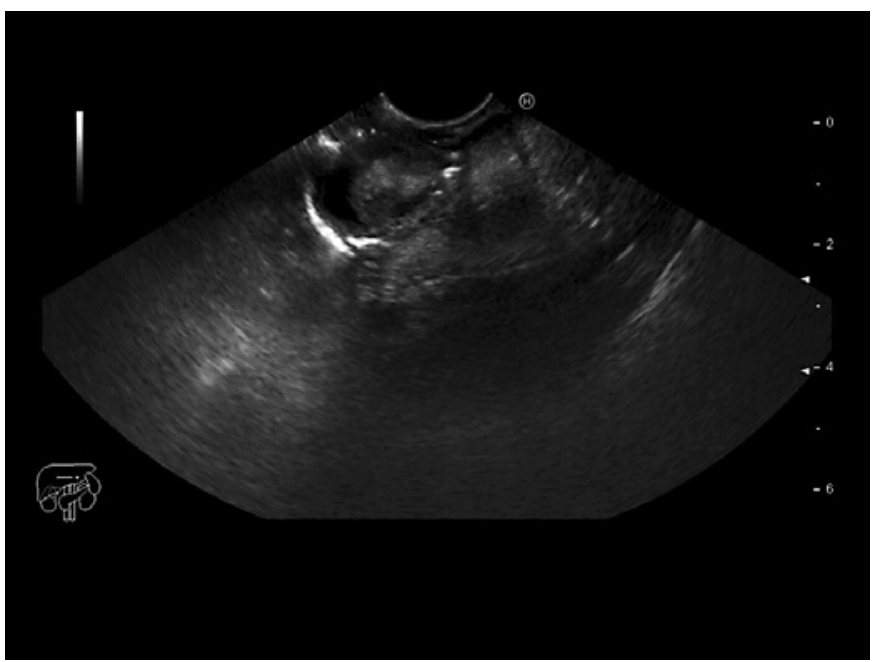

Fig. 1. Echoendoscopic image showing a $15 \times 10 \mathrm{~mm}$ isoechoic image in the distal CBD with a heterogeneous aspect without shadow cone.
Correspondence to:

Marta Moreira, marta.isabel.moreira@ulsam.min-saude.pt 
Fig. 2. ERCP images. a Endoscopic view showing a bulging papilla with normal overlying mucosa. b 20 -mm filling defect in the distal CBD compatible with a biliary stone. c Biliary sweepage with a Dormia basket revealed a $20-\mathrm{mm}$ villous polypoid lesion emanating from the bile duct into the duodenum.
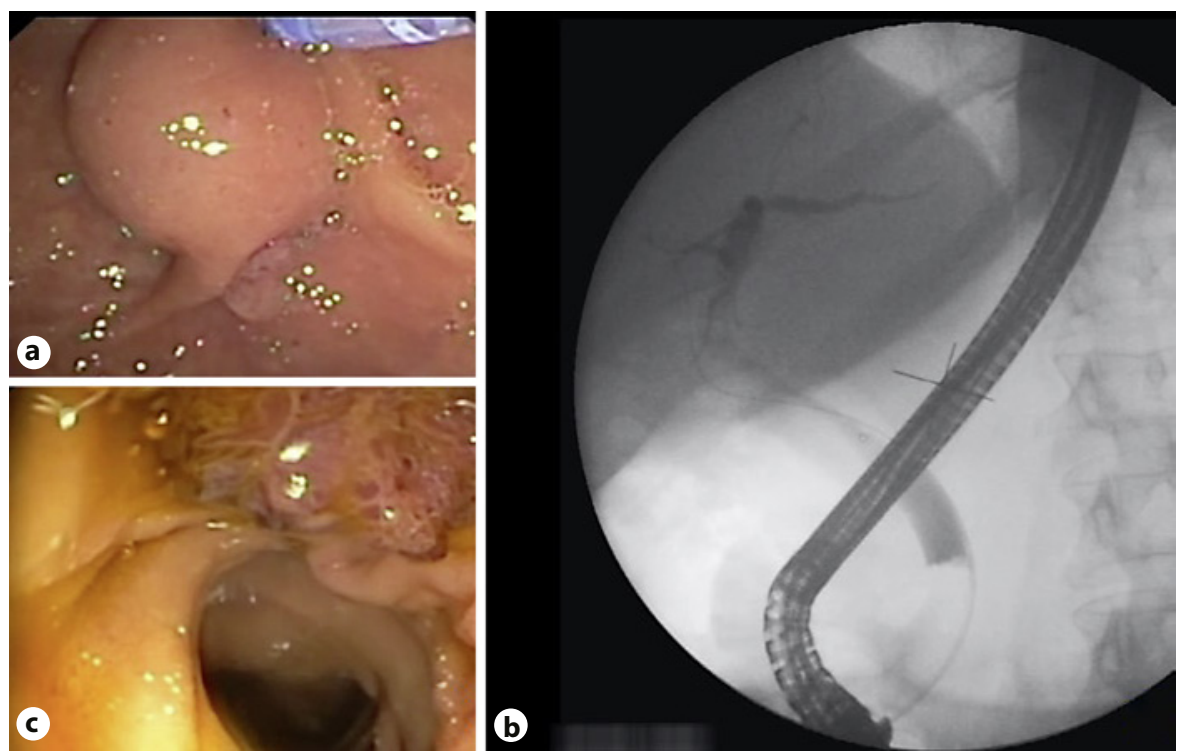

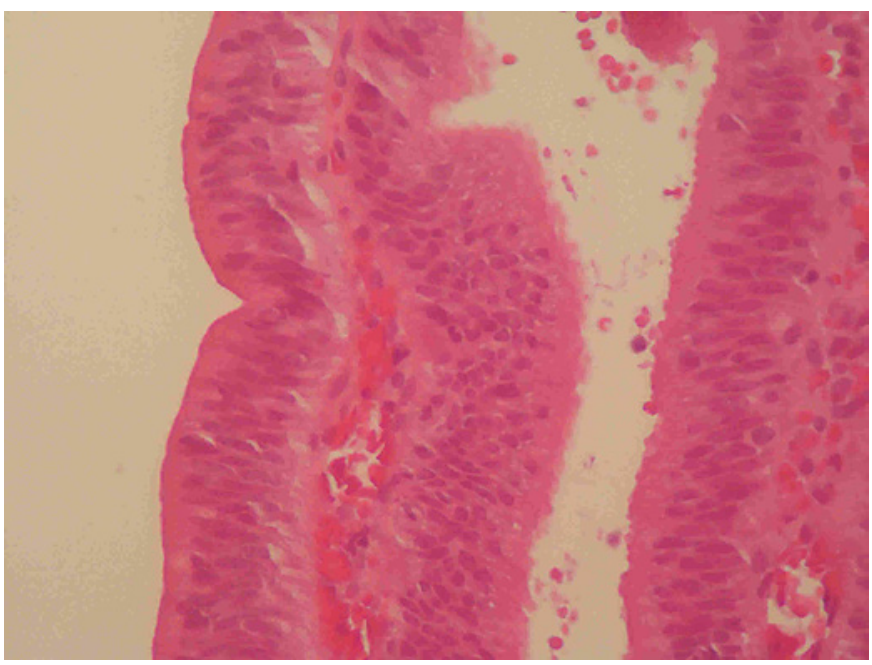

Fig. 3. Biopsy histology showing epithelium-coated papillae without atypia (HE, $\times 40)$.

overlying mucosa (Fig. 2a). The cholangiogram revealed a filling defect in the distal third of the CBD, approximately $20 \mathrm{~mm}$ in diameter, compatible with a bile duct stone (Fig. 2b). After biliary sphincterotomy, a biliary sweepage was performed using a Dormia basket revealing a villous polypoid lesion of about $20 \mathrm{~mm}$ extruding from the bile duct into the duodenum (Fig. 2c). Biopsies were taken and confirmed it to be a villous adenoma with lowgrade dysplasia (Fig. 3). Given the patient's age and comorbidities, surgery was precluded, and resection was performed using a hot snare polypectomy technique, fol- lowed by ablation with argon plasma. The etiology of the acute pancreatitis was attributed to the adenoma, after exclusion of more common etiologies (gallstones, alcohol consumption, potential drugs or toxins, triglycerides, hypercalcemia, IgG4 and autoimmune pancreatitis or anatomic anomalies). Given the patient's age and no relevant family history, genetic etiologies were not investigated.

The patient was lost to follow-up during a 4-year period and was again referred to the Gastroenterology Department because of new-onset jaundice. An ERCP was performed showing adenomatous tissue in the terminal portion of the $\mathrm{CBD}$, and biopsies were compatible with adenoma with low-grade dysplasia. Given the patient's contraindications for a surgical approach, bipolar radiofrequency $\left(\mathrm{Habib}^{\mathrm{TM}}\right)$ of the adenomatous tissue was performed with technical success. A follow-up ERCP with cholangioscopy is already scheduled.

Adenomas arising from the extrahepatic biliary tree are still poorly understood, mainly because of its very low incidence. Nevertheless, current knowledge supports the belief that these lesions may potentially evolve into carcinomas, like adenomas located elsewhere [1]. Most authors believe that removal of these adenomatous lesions may prevent the development of adenocarcinoma [1-3]. Little is known about the use of radiofrequency in biliary adenomas. In the few published case reports, a surgical approach was used. A minority of patients was maintained in surveillance without invasive treatment due to patients' risks and poor life expectancy [1].

We highlight this case because of the rarity of this pathology, the presentation as recurrent acute pancreatitis 
that, to our knowledge, is not described in the small number of case series published [1], and because of the diagnostic challenge it posed.

Consult the ERCP endoscopic video available at the following link: https://www.dropbox.com/s/g1y3m3mg2c4fjou/Adenoma\%20VBP\%20-\%20GE\%20-\%20 SD\%20480p.mov?dl=0.

\section{Statement of Ethics}

The subject has given his written informed consent to publish the case (including publication of images).

\section{Conflict of Interest Statement}

The authors have no conflicts of interest to declare.

Funding Sources

This study did not require any funding.

\section{Author Contributions}

M.M., J.F., and L.L. wrote the manuscript. R.A., J.C., and T.A. were responsible for the revision of its contents.

\section{References}

1 Loh KP, Nautsch D, Mueller J, Desilets D, Mehendiratta $\mathrm{V}$. Adenomas involving the extrahepatic biliary tree are rare but have an aggressive clinical course. Endosc Int Open. 2016 Feb;4(2):E112-7.
2 Čekas K, Rudaitis V, Beiša V, Jotautas V, Rutkauskaitė D, Meškauskas R, et al. Common bile duct villous adenoma: a case report and review of the literature. J Med Case Reports. 2016 Jan;10(1):18.
3 Hacking CP, Taylor CJ, Nathanson LK. Common bile duct polyp mimicking choledocholithiasis: a case report with laparoscopic transcystic management. Surg Laparosc Endosc Percutan Tech. 2008 Jun;18(3):290-3. 